\title{
Peran Moderasi Usia dalam Pengaruh Nilai Konsumen terhadap Loyalitas Merek \\ The Moderating Role of Age in the Effect of Consumer Value on Brand Loyalty
}

\author{
Salman Faris Insani ${ }^{1}$ \\ Ariyani Wahyu Wijayanti ${ }^{2}$ \\ Aji Rahman Purnama ${ }^{3}$ \\ Fakultas Ekonomi, Universitas Veteran Bangun Nusantara Sukoharjo 23 \\ faris.uvbn@gmail.com²
}

\begin{abstract}
The number of smartphone manufacturers offering the latest innovations has resulted in intense competition among smartphone manufacturers. This makes brand loyalty among smartphone users an interesting issue to research. On the other hand, in previous studies on the topic of brand loyalty, not many have conceptualized the moderating role of age. To answer these problems, this study aims to examine and analyze the moderating role of age in the influence relationship between perceived value and brand loyalty. The sample in this study were 100 smartphone users with the I phone brand in the Solo Raya area. The data collection method in this study used a questionnaire. Testing was carried out using Moderated Regression Analysis through IBM SPSS Statistic 23 software. The results of hypothesis testing in this study indicate that emotional value has a positive effect on brand loyalty, social value has a positive effect on brand loyalty, while functional value has a positive effect on brand loyalty. Age does not moderate the influence relationship between functional value, emotional value, and social value on brand loyalty.
\end{abstract}

Keywords: brand loyalty, smartphone, perceived value

\section{PENDAHULUAN}

Kebutuhan komunikasi merupakan hal yang penting bagi masyarakat. Kebutuhan tersebut berdampak pada meningkatnya permintaan akan berbagai jenis alat komunikasi yang mengakibatkan semakin banyaknya persaingan dalam dunia bisnis di bidang telekomunikasi. Hal ini terbukti dari banyaknya produsen smartphone yang menawarkan berbagai jenis inovasi terbaru yang berbeda dibandingkan produk sebelumnya (Tjahyadi, 2006). Kondisi ini menciptakan persaingan yang ketat diantara para produsen smartphone dan perlunya mempertahankan loyalitas merek terhadap merek smartphone mereka.

Studi ini ditujukan untuk menginvestigasi faktor-faktor yang mempengaruhi loyalitas merek dalam konteks produk smartphone di Indonesia. Loyalitas merek 
adalah konsep penting yang dapat membawa manfaat bagi perusahaan, seperti: pembelian berulang, rekomendasi merek kepada orang lain, dan pengurangan biaya pemasaran. Loyalitas merek adalah hasil dari pembelajaran konsumen terhadap pemenuhan kebutuhan seperti produk, service dan citra (Asael, 2001).

Pemahaman yang lebih baik tentang apa yang mendorong loyalitas merek terhadap merek menjadi isu penting bagi akademisi dan praktisi. Menurut Durianto et al., (2004) loyalitas merek merupakan suatu ukuran keterkaitan pelanggan kepada suatu merek. Ukuran ini mampu memberikan gambaran tentang mungkin tidaknya seorang pelanggan beralih ke merek produk lain. Seorang pelanggan yang sangat loyal kepada suatu merek tidak akan dengan mudah memindahkan suatu pembeliannya ke merek lain, apa pun yang terjadi dengan merek tersebut.

Dalam studi ini, loyalitas merek dipengaruhi oleh nilai produk yang terbagi menjadi tiga dimensi, yaitu: nilai emosional, nilai sosial, dan nilai fungsional. Konsumen dapat mengalami nilai emosional seperti kesenangan dari penggunaan smartphone dan eksplorasi (Alba \& Williams, 2013; Arruda-Filho et al., 2010). Pihlström dan Brush (2008) mengungkapkan ketika konsumen mempersepsikan nilai emosional yang lebih besar dalam suatu produk/merek, mereka menunjukkan loyalitas merek yang diukur dengan niat pembelian kembali, kemauan untuk membayar, dan mempromosikan dari mulut ke mulut. Konsumen juga dapat merasakan nilai sosial dari smartphone. Arruda-Filho et al., (2010) melakukan analisis netnografi dan menemukan bahwa konsumen dapat mengalami nilai sosial dari kepemilikan dan penggunaan smartphone. Konsumen menganggap kepemilikan smartphone dengan citra yang tinggi, sebagai simbol kemewahan dan status sosial yang lebih tinggi (Liao \& Hsieh, 2013). Selain itu, berbagi pengalaman penggunaan smartphone membantu antar pribadi konsumen untuk saling berinteraksi. Ketika konsumen merasakan nilai sosial yang lebih tinggi dari suatu produk/merek, mereka menunjukkan perilaku loyalitas merek yang lebih besar seperti menyebarkan informasi positif (Pihlström dan Brush, 2008).

Studi ini mengkonsepkan peran moderasi dari usia, dalam hubungan pengaruh antara persepsi nilai dan loyalitas merek. Harverila (2012) serta Kumar 
dan Lim (2008), berpendapat bahwa kebutuhan motivasi untuk penggunaan telepon seluler adalah spesifik berdasarkan usia. Efek dari ketiga tipe nilai terhadap loyalitas merek dapat bervariasi sesuai dengan usia konsumen (Barutcu, 2007; Coates, 2001; Park et al., 2013; Persaud \& Azhar, 2012). Dalam konteks produk smartphone, konsumen yang lebih muda adalah pengguna smartphone yang lebih antusias dibandingkan dengan konsumen yang lebih tua.

Penelitian ini merupakan replikasi parsial dari studi yang dilakukan oleh Yeh et al., (2016) dengan setting waktu dan tempat yang berbeda. Studi yang dilakukan oleh Yeh et al., (2016) diterapkan pada pengguna smartphone secara umum di Taiwan. Berbeda dengan studi tersebut, penelitian ini diaplikasikan dalam konteks pertumbuhan dan persaingan industri smartphone di Indonesia. Studi ini mengkonsepkan tiga faktor penentu loyalitas merek smartphone berdasarkan pada nilai konsumen. Penelitian ini juga menjelaskan efek moderasi dari perbedaan usia pada proses penentuan loyalitas merek smartphone.

Merek smartphone yang dipilih menjadi objek penelitian dalam studi ini adalah iPhone. IPhone adalah jajaran telepon pintar yang dirancang dan dipasarkan oleh Apple Inc. IPhone memang sangat krusial dalam menghasilkan pundi-pundi uang bagi perusahaan Apple. Namun, saat ini penjualannya makin turun seiring stagnasi pasar smartphone global. Pada tiga bulan pertama 2019, Apple menjual iPhone senilai USD 31 miliar. Namun, pada tahun 2020 di periode yang sama, persentasenya anjlok menjadi $17 \%$ (inet.detik.com). Secara keseluruhan, pertumbuhan penjualan lini iPhone stagnan sejak 2017 lalu. Tren tersebut terus berlanjut bahkan semakin menurun di tahun 2019 dan 2020. Sejauh ini, Apple telah menjual 213 juta unit iPhone. Menurut ramalan firma analis Nomura, penjualan iPhone bakal menurun menjadi 204 juta unit pada tahun 2019, kemudian 200 juta unit pada tahun 2020. Adanya fenomena penurunan penjualan tersebut memerlukan usaha strategis yang ditujukan untuk mempertahankan loyalitas merek dari penggunanya. Hal tersebut menjadi fenomena bisnis yang melatarbelakangi studi ini. 


\section{KAJIAN PUSTAKA DAN PERUMUSAN HIPOTESIS}

\section{Loyalitas merek}

Loyalitas merek merupakan komitmen konsumen yang kuat untuk kembali membeli produk atau penawaran kembali berlangganan layanan secara konsisten di masa yang akan datang, sehingga menyebabkan pembelian berulang merek yang sama atau seperangkat produk tanpa dipengaruhi situasi (Sadasivan, 2011). Loyalitas merek adalah kondisi yang dapat membawa banyak manfaat bagi perusahaan, seperti pembelian berulang dan rekomendasi merek kepada orang lain, dan kemudian dapat mengurangi biaya pemasaran (Tjahyadi, 2006). Dapat di simpulkan bahwa loyalitas merek adalah komitmen konsumen untuk melakukan pembelian kembali terhadap produk ataupun jasa.

\section{Nilai Fungsional}

Oesman (2010) mengemukakan bahwa nilai fungsional berkaitan langsung dengan fungsi yang diberikan oleh produk atau layanan kepada konsumen. Jika memiliki keunggulan secara fungsional, maka sebuah merek mendominasi kategori. Menurut Surachman (2008), nilai fungsional yakni nilai yang diperoleh dari atribut produk yang memberikan kegunaan fungsional pada pelanggan. Nilai tersebut berkaitan langsung dengan fungsi yang diberikan oleh produk/layanan kepada pelanggan. Konsumen mendapatkan nilai fungsional jika kinerja atribut produk teknologi bermanfaat lebih, mudah digunakan, dan inovatif. Produk teknologi dengan penampilan yang menarik dan desain yang inovatif, secara positif memunculkan perasaan konsumen. Smartphone adalah produk teknologi tercanggih, dengan mengintegrasikan komponen seperti prosesor, kamera, panel display, baterai, dan kapasitas memori/penyimpanan ke perangkat genggam. Smartphone adalah perangkat telekomunikasi dan alat yang bisa digunakan untuk mendengarkan musik, mengedit dokumen, mengambil gambar, merekam gambar, dan bisa digunaan untuk proses pembelajaran, maka dari itu nilai fungsional mempengaruhi konsumen menjadi loyal terhadap merek smartphone (Liao \& Hsieh, 2013; Park \& Han, 2013). Berdasarkan uraian di atas dapat disimpulkan hipotesis sebagai berikut:

H1: Nilai fungsional berpengaruh positif terhadap loyalitas merek. 


\section{Nilai Emosional}

Nilai emosional yaitu utilitas yang berasal dari perasaan atau afektif/emosi positif yang ditimbulkan dari pengalaman mengkonsumsi produk (Sweeney \& Soutar, 2001). Nilai emosional merupakan kepuasan emosional dan kesenangan yang diperoleh konsumen melalui penggunaan atau konsumsi barang atau jasa tertentu. Nilai emosional merupakan utilitas yang dirasakan berasal dari kapasitas alternatif untuk membangkitkan perasaan positif (Effendy \& Kunto, 2013). Konsumen dapat mengalami nilai emosional seperti kesenangan dari penggunaan dan eksplorasi pada smartphone (Alba \& Williams, 2013; ArrudaFilho et al.,2010). Liao dan Hsieh (2013) juga menunjukkan bahwa fashionable dan penampilan estetika smartphone berkontribusi pada nilai emosional. Pihlstrom dan Brush (2008) mengungkapkan ketika konsumen merasakan nilai emosional yang lebih besar dalam suatu produk/merek, mereka menunjukkan sikap lebih loyal yang diukur dengan niat pembelian kembali, kemauan untuk membayar, dan memasarkan dari mulut ke mulut. Berdasarkan uraian di atas dapat disimpulkan hipotesis sebagai berikut:

H2: Nilai emosional berpengaruh positif terhadap loyalitas merek.

\section{Nilai Sosial}

Nilai Sosial berhubungan dengan persepsi konsumen atas produk yang dinilai dari segi sosial (Eryadi \& Yuliana, 2016). Nilai sosial merupakan suatu keadaan dimana konsumen merasa tingkatan sosial mereka meningkat, saat menggunakan produk ataupun jasa (Widiaputri et al., 2018). Arruda-Fidho et al (2010) melakukan analisis netnografi dan menemukan bahwa konsumen dapat mengalami nilai sosial dari kepemilikan dan penggunaan smartphone. Mereka dapat melihat kepemilikan Smartphone sebagai simbol kemewahan dan status sosial yang lebih tinggi (Liao \& Hsieh, 2013). Selain itu, berbagi pengalaman penggunaan smartphone membantu interaksi antar konsumen, efek tersebut menimbulkan efek loyalitas merek terhadap produk Smartphone. Berdasarkan uraian di atas dapat di simpulkan hipotesis sebagai berikut:

H3: Nilai sosial berpengaruh positif terhadap loyalitas merek.

\section{Moderasi usia}


Harverila (2012) dan Kumar dan Lim (2008), berpendapat bahwa konsumen yang lebih muda adalah pengguna smartphone yang lebih antusias dibandingkan dengan konsumen yang lebih tua. Berdasar penelitian yang dilakukan oleh Coates (2001), konsumen yang lebih muda, menggunakan lebih banyak fungsi smartphone, seperti: mengirim pesan teks, satelit navigasi, dan pengeditan foto, sedangkan konsumen yang lebih tua cenderung hanya gunakan untuk komunikasi. Dapat disimpulkan bahwa usia mempengaruhi penggunaan suatu produk, di mana usia yang lebih muda menggunakan fungsi suatu produk secara menyeluruh, sedangkan konsumen dengan usia tua hanya menggunakan fungsi suatu produk pada beberapa fitur saja. Kompleksitas fungsi, menu yang kurang ramah pengguna, dan instruksi penggunaan yang tidak jelas dapat menghalangi konsumen yang lebih tua dalam menjelajahi banyak aplikasi smartphone. Hal tersebut menyebabkan konsumen yang lebih tua, menganggap kurangnya nilai fungsional dan emosional dari sebuah smartphone (Kurniawan, 2008). Sebaliknya, konsumen yang lebih muda mungkin terlibat dalam tingkatan yang tinggi dalam penggunaan ponsel (Walsh et al., 2010), dan lebih cenderung menghargai desain penampilan (Park et al., 2013; Srivastava, 2005). Berdasarkan uraian di atas dapat disimpulkan hipotesis sebagai berikut:

H4a: Pengaruh positif nilai fungsional terhadap loyalitas merek lebih besar pada usia yang lebih muda.

H4b: Pengaruh positif nilai emosional terhadap loyalitas merek lebih besar pada usia yang lebih muda.

H4c: Pengaruh positif nilai sosial terhadap loyalitas merek lebih besar pada usia yang lebih muda.

H4d: Pengaruh positif identifikasi merek terhadap loyalitas merek lebih besar pada usia yang lebih muda.

Berdasarkan hipotesis yang dirumuskan, pengaruh antar variabel dapat digambarkan dalam bentuk model penelitian sebagai berikut: 


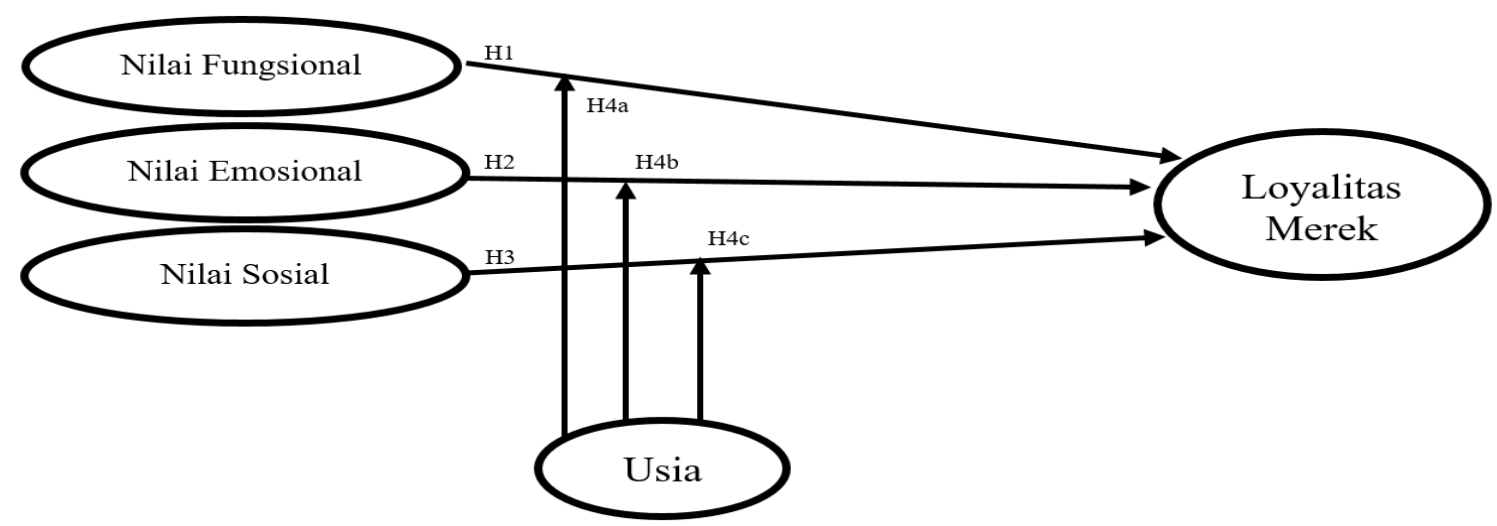

Gambar 1. Model Penelitian

\section{METODE PENELITIAN}

\section{Populasi dan Sampel}

Populasi dalam penelitian ini adalah pengguna iPhone di kawasan solo raya. Pengambilan sampel dalam penelitian ini menggunakan desain non probability sampling melalui metode purposive sampling (Sugiyono, 2004; Sekaran, 2006). Kriteria yang digunakan dalam penelitian ini adalah pengguna iPhone di kawasan solo raya yang menggunakan iPhone lebih dari 3 bulan serta bersedia untuk menjadi responden. Pengambilan data yang dipergunakan dengan cara melakukan penyebaran kuisoner yang berisikan 19 butir pernyataan sejumlah 100 kuesioner. Hal ini didasarkan pada kriteria sampel minimal menurut ferdinand (2016). Karakteristik responden yang diperoleh dan diolah melalui software IBM SPSS Statistic 23 disajikan pada Tabel 1 sebagai berikut:

Tabel 1

Karakteristik Responden

\begin{tabular}{|c|c|c|}
\hline Karakteristik & Frekuensi & Presentase $(\%)$ \\
\hline & Jenis kelamin & \\
\hline Pria & 46 & 46,0 \\
\hline Wanita & 54 & 54,0 \\
\hline & Usia & \\
\hline$<21$ Tahun & 53 & 53,0 \\
\hline$>21$ Tahun & 47 & 47,0 \\
\hline \multirow{3}{*}{$<3$ Bulan } & Lama penggunaa & \\
\hline & 100 & 100 \\
\hline & Pendidikan terakl & \\
\hline \multirow{4}{*}{$\begin{array}{c}\text { SMA } \\
\text { D3 } \\
\text { S1 } \\
\text { S2 } \\
\end{array}$} & 86 & 86,0 \\
\hline & 4 & 4,0 \\
\hline & 10 & 10,0 \\
\hline & o & 0,0 \\
\hline
\end{tabular}

Sumber: Olahan data, 2020 


\section{Definisi Operasional dan Pengukuran Variabel}

Dalam rangka untuk memberikan gambaran dan pemahaman yang lebih baik tentang variabel yang digunakan, berikut definisi operasional dari masing-masing variabel dalam studi ini. Setiap item pernyataan yang digunakan, diukur menggunakan Skala Likert dengan 5 alternatif pilihan, yaitu: Sangat Tidak Setuju (STS), Tidak Setuju (TS), Netral (N), Setuju (S) dan Sangat Setuju (SS).

1. Nilai fungsional

Nilai fungsional dalam studi ini, didefinisikan sebagai penilaian rasional dari pengguna Iphone di kawasan solo raya, yang dihubungkan dengan fungsi produk dan efisiensi dari smartphone tersebut. Pengukuran variabel nilai fungsional menggunakan 4 item pernyataan diadopsi dari Yeh et al., (2016).

2. Nilai emosional

Nilai emosional dalam studi ini didefinisikan sebagai utilitas yang berasal dari emosi positif yang dirasakan oleh pengguna Iphone di kawasan solo raya yang ditimbulkan dari pengalaman penggunaan produk. Pengukuran variabel nilai emosional menggunakan 4 item pernyataan diadopsi dari Yeh et al., (2016).

3. Nilai sosial

Nilai sosial dalam studi ini, didefinisikan sebagai nilai yang diperoleh pengguna Iphone di kawasan solo raya melalui penggunaan atau konsumsi barang atau jasa, apabila dikaitkan dengan hubungan sosialnya dengan orang lain. Pengukuran variabel nilai sosial menggunakan 4 item pernyataan diadopsi dari Yeh et al., (2016).

4. Loyalitas merek

Loyalitas merek dalam studi ini, didefinisikan sebagai komitmen pengguna Iphone di kawasan solo raya, yang kuat untuk kembali membeli produk di masa yang akan datang, sehingga menyebabkan pembelian berulang merek yang sama. Pengukuran variabel ini menggunakan 4 item pernyataan diadopsi dari Yeh et al., (2016).

5. Moderasi usia 
Usia dalam penelitian ini di kategorikan menjadi dua yaitu usia dibawah 21 tahun untuk mewakili usia muda, dan 21 tahun ke atas untuk mewakili usia dewasa/tua. Pengkategorian ini di dasari oleh undangundang republik Indonesia No. 4/ 1979 tentang kesejahteraan anak. Untuk usia muda (Di bawah 21 tahun) dalam penelitian ini di beri kode 1, sedangkan usia tua (Di atas 21 tahun) di beri kode 2 .

\section{ANALISIS DAN PEMBAHASAN}

\section{Hasil Uji Instrumen Penelitian}

Tabel 2.

KMO and Bartlett's Test

\begin{tabular}{llr}
\hline Kaiser-Meyer-Olkin Measure of Sampling Adequacy. &, 692 \\
& Approx. Chi-Square & 535,587 \\
Bartlett's Test of Sphericity & Df & 171 \\
& Sig. &, 000 \\
\hline
\end{tabular}

Sumber: Olahan data, 2020

Pengujian instrumen dalam penelitian ini dilakukan melalui dua tahapan, yaitu: uji validitas dan uji reliabilitas melalui software IBM SPSS Statistic 23. Dari uji validitas yang telah dilakukan, menunjukkan hasil nilai KMO Measure of sampling Adequecy (MSA) dalam penelitian ini sebesar 0,692. Karena nilai KMO MSA di atas 0,5 serta nilai Barlett's test dengan Chi-square= 535,587 dan signifikansi pada $0,000<0,05$, dapat disimpulkan bahwa uji analisis faktor dapat dilanjutkan (lihat tabel 2). Dari jumlah total 100 responden dan lima variabel utama yang berjumlah 19 item kuesioner, menunjukkan hasil yang dikatakan valid, karena telah terekstrak sempurna dan memiliki factor loading $>0.50$ (lihat tabel 3). Selanjutnya, dilakukan pengujian reliabilitas yang bertujuan untuk mengetahui konsistensi item-item pernyataan yang digunakan. Hasilnya dapat disimpulkan bahwa secara umum, semua variabel penelitian dinyatakan reliabel dengan nilai Cronbach'Alpha > 0,60 (lihat tabel 4). 
Tabel 3. Hasil uji validitas

\begin{tabular}{|c|c|c|c|c|c|}
\hline & \multicolumn{5}{|c|}{ Component } \\
\hline & 1 & 2 & 3 & 4 & 5 \\
\hline 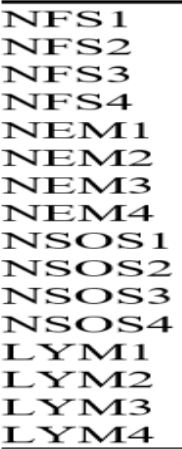 & $\begin{array}{r}.706 \\
.644 \\
.709 \\
.716\end{array}$ & $\begin{array}{r}679 \\
.712 \\
732 \\
.761\end{array}$ & $\begin{array}{r}.522 \\
.768 \\
.811 \\
.584\end{array}$ & & $\begin{array}{r}645 \\
.704 \\
.696 \\
.714\end{array}$ \\
\hline
\end{tabular}

Sumber: Olahan data, 2020

Tabel 4. Hasil uji reliabilitas

\begin{tabular}{lc}
\hline \multicolumn{1}{c}{ Variabel } & Cronbach'Alpha \\
\hline Nilai Fungsional & 0,734 \\
Nilai Emosional & 0,694 \\
Nilai Sosial & 0,672 \\
Loyalitas Merek & 0,724 \\
\hline
\end{tabular}

Sumber: Olahan data, 2020

\section{Uji Hipotesis}

Pengujian hipotesis dalam studi ini dilakukan menggunakan alat analisis Moderated Regression Analysis melalui software IBM SPSS Statistic 23. Pada tabel 5 menunjukkan sebanyak 3 model regresi yang diuji untuk moderasi usia. Model pertama menguji pengaruh variabel nilai fungsional, nilai emosional, dan nilai sosial terhadap loyalitas merek. Hasilnya nilai emosional dan nilai sosial berpengaruh positif terhadap loyalitas merek ( $\mathrm{p}<0,05$; t-hitung $>1.96)$. Namun, nilai fungsional tidak berpengaruh terhadap loyalitas merek dalam studi ini ( $>$ >0.05; t-hitung<1.96). Pada model kedua, diuji pengaruh nilai fungsional, nilai emosional, nilai sosial, dan umur terhadap loyalitas merek. Hasilnya nilai emosional dan nilai sosial berpengaruh positif terhadap loyalitas merek $(\mathrm{p}<0,05$; $\mathrm{t}-$ hitung>1.96). Namun, nilai fungsional dan umur tidak berpengaruh terhadap loyalitas merek ( $>0.05$; t-hitung<1.96). Pada model ketiga, dilakukan pengujian pengaruh variabel perkalian antara nilai fungsional, nilai emosional, dan nilai sosial dengan usia terhadap loyalitas merek. Hasilnya, usia tidak memoderasi 
variabel nilai fungsional, nilai emosional, dan nilai sosial terhadap loyalitas merek ( $\mathrm{p}>0.05$; t-hitung $<1.96)$.

Tabel 5. Hasil uji moderasi usia

\begin{tabular}{|c|c|c|c|}
\hline & \multicolumn{3}{|c|}{ Coyalitas Merek } \\
\hline & $\begin{array}{l}\text { Mrandel } 1 \\
\text { G(sig) }\end{array}$ & $\begin{array}{c}\text { Mrandel } 2 \\
\text { (csing) }\end{array}$ & $\begin{array}{l}\text { Madiel } 3 \\
\text { Acsigg) }\end{array}$ \\
\hline Nilai fungsional (NFS) & $\left(\begin{array}{l}1.597 \\
(0,114)\end{array}\right.$ & $\begin{array}{l}1,554 \\
0,124\end{array}$ & $\begin{array}{l}-0,361 \\
(0,719)\end{array}$ \\
\hline Nilai Emosional (NEM) & 2,505 & 2,456 & 1,440 \\
\hline Nilai sosial & 2,319 & $\left(\begin{array}{l}2,281 \\
0,025)\end{array}\right.$ & $(0.626)$ \\
\hline Jmur (U) & & $\begin{array}{l}0,129 \\
(0,898)\end{array}$ & $\begin{array}{l}1,0,90 \\
(0,279)\end{array}$ \\
\hline NFS $\times U$ & & & $(0.423$ \\
\hline INEM $\times$ U & & & -0.523 \\
\hline ISOS $x U$ & & & $\begin{array}{l}(0,602) \\
-0.124 \\
(0,902)\end{array}$ \\
\hline$\Delta \mathbf{R}^{2}$ & 0,247 & 0,01010 & 0,043 \\
\hline $\mathbb{R}^{2}$ & 0,247 & 0,247 & 0,200 \\
\hline Adiusted $\mathbf{R}^{2}$ & 0,215 & 0,207 & 0,219 \\
\hline $\mathbf{F}$ & $\left(\begin{array}{l}7,774 \\
(0,000)\end{array}\right.$ & $\begin{array}{c}6,158 \\
(0,0100)\end{array}$ & $4,081(0,000)$ \\
\hline
\end{tabular}

Sumber: Olahan data, 2020

\section{HASIL DAN PEMBAHASAN}

\section{Pengaruh Nilai Fungsional terhadap Loyalitas Merek}

Hasil penelitian ini menunjukkan bahwa nilai fungsional tidak berpengaruh terhadap loyalitas merek. Hasil ini dapat dimungkinkan karena pengguna Iphone lebih memperhatikan kesan dalam penggunaan smartphone merek Iphone, dibandingkan fungsi dari smartphone itu sendiri. Hal ini menunjukkan bahwa standar kualitas yang dapat diterima, keandalan kinerja, serta nilai produk yang sesuai dengan yang dibayarkan pada ponsel iPhone, tidak mampu mendorong konsumen untuk melakukan pembelian ulang di masa mendatang dan rekomendasi positif atas Iphone kepada orang lain. Hasil penelitian ini berbeda dengan studi yang dilakukan Yeh et al., (2016) yang menyatakan bahwa nilai fungsional berpengaruh positif dengan loyalitas merek.

\section{Pengaruh Nilai Emosional terhadap Loyalitas Merek}

Hasil penelitian ini menunjukkan nilai emosional berpengaruh terhadap loyalitas merek. Hasil ini dapat dimungkinkan karena pengguna Iphone lebih memperhatikan pengaruh nilai emosional dalam penggunaan smartphone merek iPhone. Hal ini menunjukkan bahwa tampilan fisik dan pengalaman yang 
menarik, mampu memberi kesenangan bagi pengguna iPhone, serta dapat membuat konsumen mengalami nilai emosional seperti kesenangan dari penggunaan dan eksplorasi pada smartphone (Alba \& Williams, 2013; ArrudaFilho et al., 2010). Liao dan Hsieh (2013) juga menunjukkan bahwa kesan fashionable dan penampilan estetika smartphone berkontribusi pada nilai emosional. Pihlström dan Brush (2008) mengungkapkan ketika konsumen merasakan nilai emosional yang lebih besar dalam suatu produk/merek, mereka menunjukkan lebih loyal yang diukur dengan niat pembelian kembali, kemauan untuk membayar, dan memasarkan dari mulut ke mulut. Hasil penelitian ini sejalan dengan studi yang dilakukan Yeh et al., (2016) yang menyatakan bahwa nilai emosional berpengaruh positif terhadap loyalitas merek.

\section{Pengaruh Nilai Sosial terhadap Loyalitas Merek}

Hasil penelitian ini, menunjukkan bahwa nilai sosial berpengaruh positif terhadap loyalitas merek. Hasil ini dapat dimungkinkan karena pengguna Iphone mendapatkan kesan sosial dalam penggunaan smartphone merek Iphone dan citra diri di mata orang lain, dipersepsikan berbeda, serta meningkatkan hubungan sosial dengan orang lain. Hal ini dapat membuat pengguna Iphone merasakan adanya nilai sosial dari smartphone. Arruda-Fidho et al., (2010) melakukan analisis netnografi dan menemukan bahwa konsumen dapat mengalami nilai sosial dari kepemilikan dan penggunaan smartphone. Mereka dapat melihat kepemilikan smartphone sebagai simbol kemewahan dan status sosial yang lebih tinggi (Liao \& Hsieh, 2013). Selain itu, berbagi pengalaman penggunaan smartphone membantu interaksi interpersonal konsumen, efek tersebut menimbulkan efek loyalitas merek terhadap produk smartphone. Hasil penelitian ini sejalan dengan studi yang dilakukan Yeh et al., (2016) yang menyatakan bahwa nilai sosial berpengaruh positif terhadap loyalitas merek.

\section{Pengaruh Nilai Fungsional terhadap Loyalitas Merek lebih besar pada pengguna yang berusia lebih muda}

Hasil penelitian ini menunjukkan tidak ada pengaruh antara nilai fungsional dan loyalitas merek yang lebih besar, pada pengguna berusia lebih muda. Hal ini menunjukkan bahwa usia muda tidak memperkuat pengaruh nilai 
fungsional terhadap loyalitas merek. Hal ini dimungkinkan karena tidak ada perbedaan usia, dalam kekuatan pengaruh nilai fungsional terhadap loyalitas merek. hasil penelitian ini berbeda dengan hasil penelitian Yeh et al., (2016) yang menyatakan bahwa pengaruh positif antara nilai fungsional dan loyalitas merek lebih besar pada pengguna yang berusia lebih muda.

\section{Pengaruh Nilai Emosional terhadap Loyalitas Merek lebih besar pada pengguna yang berusia lebih muda}

Hasil penelitian ini menunjukkan usia muda tidak memperkuat pengaruh nilai emosional terhadap loyalitas merek pada pengguna yang berusia lebih muda. Hal ini dimungkinkan karena pengguna Iphone yang berusia lebih muda (kurang dari 21 tahun) dan pengguna yang lebih tua (lebih dari 21 tahun), sama-sama tidak memperhatikan nilai emosional dari produk Iphone untuk membentuk loyalitas merek. Hasil penelitian ini berbeda dengan hasil penelitian Yeh et al., (2016) yang menyatakan bahwa pengaruh positif antara nilai emosional dan loyalitas merek lebih besar pada pengguna yang berusia lebih muda.

\section{Pengaruh Nilai Sosial terhadap Loyalitas Merek lebih besar pada pengguna yang berusia lebih muda}

Hasil penelitian ini menunjukkan usia muda tidak memperkuat pengaruh nilai sosial dan loyalitas merek pada pengguna yang berusia lebih muda. Hal ini dimungkinkan karena pengguna iPhone yang berusia lebih muda (kurang dari 21 tahun) dan pengguna yang lebih tua (lebih dari 21 tahun) sama-sama tidak memperhatikan nilai sosial dari produk iPhone untuk membentuk loyalitas merek. Hasil penelitian ini berbeda dengan hasil penelitian Yeh et al., (2016), yang menyatakan bahwa pengaruh positif antara nilai sosial dan loyalitas merek, lebih besar pada pengguna yang berusia lebih muda.

\section{KESIMPULAN, KETERBATASAN DAN SARAN}

Berdasarkan hasil analisis di atas, maka dapat disimpulkan sebagai berikut: nilai konsumen yang terdiri dari nilai fungsional, nilai emosional, dan nilai social, memiliki pengaruh pada loyalitas merek hanya pada variabel nilai emosional dan nilai social, sedangkan nilai fungsional tidak berpengaruh pada 
pengguna smartphone merek iphone di kawasan solo raya. Usia tidak memoderasi pengaruh nilai konsumen (nilai fungsional, nilai emosional, dan nilai sosial) pada loyalitas merek.

Keterbatasan penelitian ini adalah tempat penelitian yang digunakan dalam penelitian ini hanya berfokus pada pengguna iphone di kawasan solo raya, sehingga terdapat keterbatasan peneliti dalam memperoleh responden. Dengan keterbatasan tersebut, maka hasil dari penelitian ini belum bisa menjadi acuan untuk mengukur loyalitas merek pengguna iPhone secara keseluruhan. Untuk penelitian selanjutnya, perlu dipahami bahwa konteks studi ini hanya diterapkan pada penggunaan produk smartphone, yang dikategorikan sebagai produk dengan keterlibatan tinggi (Wolsh et al., 2011). Peran keterlibatan produk dalam mempengaruhi identifikasi merek dan loyalitas merek telah diketahui dari studi sebelumnya (Stokbugersaur at al., 2012). Hal ini menyebabkan generalisasi pada studi ini relatif terbatas. Untuk itu, studi selanjutnya dapat diterapkan pada produk dengan keterlibatan lebih rendah. Penggunaan variabel usia dalam penelitian ini hanya didasarkan pada perspektif usia kronologis (usia fisik atau biologis). Penelitian selanjutnya dapat dikembangkan dalam konteks usia kognitif (usia mental atau tingkat kedewasaan) sebagai prediktor dari perilaku konsumen (Chang, 2008).

Saran untuk perusahaan, hasil penelitian ini menunjukkan adanya pengaruh nilai emosional terhadap loyalitas merek. Untuk itu, produsen Iphone diharapkan mempertahankan dan mengembangkan daya tarik dan mempertahankan fitur yang dapat menyenangkan pengguna Iphone. Produsen Iphone juga diharapkan tetap mempertahankan citra positif pada pengguna agar pengguna tersebut memperoleh citra positif di mata orang lain. Iphone juga diharapkan mempertahankan dan meningkatkan dukungan perangkatnya terhadap aplikasi media sosial dan layanan pesan singkat, agar dapat membantu menjaga hubungan sosial bagi penggunanya. 


\section{REFERENCES}

Alba, J. W., \& Williams, E. F. (2013). Pleasure principles: a review of research on hedonic consumption. Journal of Consumer Psychology, 23(1), 2-18.

Arifin, S. Suharyono. W. (2013) Pengaruh Perceived Price dan PerceivedValue padaProduk Bundling Terhadap Minat Beli (Survei Minat Beli handphone BlackBerry-Indosat pada mahasiswa Jurusan Administrasi Fakultas Ilmu Administrasi Universitas Brawijaya). Jurnal administrasi bisnis. Vol 1.No. 2.

Arruda-Filho, E. J. M., Cabusas, J. A., \& Dholakia, N. (2010). Social behavior and brand devotion among iPhone innovators. International Journal of Information Management, 30(6), 475-480.

Harverila, M. (2012). What do we want specifically from the cell phone? An agerelated study. Telematics and Informatics, 29(1), 110-122.

Hasan, B. (2010). Exploring gender differences in online shopping attitude. Computers in Human Behavior, 26(4), 597-601.

Fatimah kartini bohang, tekno.kompas.com, penjualan iphone diprediksi melem pem hingga 2020, https://tekno.kompas.com, penjualan-iphone-diprediksimelempemhingga-2020.

Ikramuddin, Adam, M., Sofyan, H. and Faisal, 2017. The Relationship of Perceived Value, Service Quality, Brand Trust, and Brand Loyalty. A Literature Review. Expert Journal of Marketing, 5(2), pp. 72-77.

Indriantoro, Nur., Bambang Supomo. 2018. Metodologi Penelitian Bisnis Untuk Akutansi dan Manajemen. Yogyakarta: ANDI dan BPFE.

Fino Yurio Kristo, detikinet, 2019. penjualan iPhone Turun Apple Geber Strategi Ciamik, inet.detik.com/consumer/d-4532592/penjualan-iphone-turun-applegeber-strategiciamik

Kim, H. W., Gupta, S., \& Koh, J. (2011). Investigating the intention to purchasedigital items in social networking communities: a customer value perspective. Information \& Management, 48(6), 228-234.

Lee, S., Ha, S., \& Widdows, R. (2011). Consumer responses to hightechnologyproducts: product attributes, cognition, and emotions. Journal of Business Research, 64(11), 1195-1200.

Liao, C. H., \& Hsieh, I. Y. (2013). Determinants of consumer's willingness to purchase gray-market smartphones. Journal of Business Ethics, 114(3), $409-424$. 
http://journal.univetbantara.ac.id/index.php/jbfe

Okazaki, S., \& Mendez, F. (2013). Exploring convenience in mobile commerce: moderating effects of gender. Computers in Human Behavior, 29(3), 12341242.

Osman, Z., Mohamad, R.K., and Mohamad, L., 2016. Mediating effect of customer satisfaction on service qualityand trust relationship in Malaysian Banking Industry. International Journal of Advances in Management, Economic and Entrepreneurship, 3, Issue 1, pp.10-19.

Park, J., \& Han, S. H. (2013). Defining user value: a case study of a smartphone. International Journal of Industrial Ergonomics, 43(4), 274-282.

Rocereto, J. F., \& Mosca, J. B. (2012). Self-concept, gender, and product type: an investigation of brand loyalty. Journal of Business \& Economics Research, $10(1), 25-36$.

Yeh, C.H., Wanga, Y.S., Yieh, K. Predicting smartphone brand loyalty: Consumer value and consumer brand identification perspectives. International Journal of Information Management 36 (2016) 245-257. 


\section{LAMPIRAN INSTRUMENT PENELITIAN}

\section{Nilai fungsional}

\begin{tabular}{|c|l|c|c|c|c|c|}
\hline \multirow{2}{*}{ No } & \multicolumn{1}{|c|}{ Pernyataan } & \multicolumn{3}{|c|}{ Jawaban } \\
\cline { 3 - 6 } & \multicolumn{1}{|c|}{ STS } & TS & N & S & SS \\
\hline 2 & $\begin{array}{l}\text { IPhone memiliki standar kualitas yang } \\
\text { dapat diterima. }\end{array}$ & & & & & \\
\hline 3 & $\begin{array}{l}\text { IPhone dapat diandalkan kinerjanya. } \\
\text { IPhone memiliki kualitas yang } \\
\text { memuaskan. }\end{array}$ & & & & & \\
\hline 4 & $\begin{array}{l}\text { IPhone menawarkan nilai yang baik } \\
\text { untuk uang yang saya bayarkan ketika } \\
\text { membelinya }\end{array}$ & & & & \\
\hline
\end{tabular}

\section{Nilai Emosional}

\begin{tabular}{|c|l|c|c|c|c|c|}
\hline \multirow{2}{*}{ No } & \multicolumn{1}{|c|}{ Pernyataan } & \multicolumn{3}{|c|}{ Jawaban } \\
\cline { 3 - 6 } & \multicolumn{1}{|c|}{ STS } & TS & N & S & SS \\
\hline 1 & $\begin{array}{l}\text { Saya suka dengan tampilan fisik dari } \\
\text { Iphone. }\end{array}$ & & & & \\
\hline 2 & Iphone memiliki fitur-fitur yang menarik. & & & & & \\
\hline 3 & $\begin{array}{l}\text { Penggunaan Iphone memberikan } \\
\text { pengalaman yang mengasyikkan. }\end{array}$ & & & & \\
\hline 4 & Saya senang menggunakan iPhone. & & & & & \\
\hline
\end{tabular}

Nilai Sosial

\begin{tabular}{|c|l|c|c|c|c|c|}
\hline \multirow{2}{*}{ No } & \multicolumn{1}{|c|}{ Pernyataan } & \multicolumn{3}{|c|}{ Jawaban } \\
\cline { 2 - 6 } & \multicolumn{1}{|c|}{ STS } & TS & N & S & SS \\
\hline 1 & $\begin{array}{l}\text { Menggunakan Iphone meningkatkan citra } \\
\text { diri saya di mata orang lain }\end{array}$ & & & & \\
\hline 2 & $\begin{array}{l}\text { Menggunakan Iphone membuat saya } \\
\text { dipersepsikan berbeda. }\end{array}$ & & & & \\
\hline 3 & $\begin{array}{l}\text { Menggunakan iPhone dapat membantu } \\
\text { saya untuk menjaga hubungan sosial } \\
\text { dengan orang lain }\end{array}$ & & & & & \\
\hline 4 & $\begin{array}{l}\text { Menggunakan Iphone dapat } \\
\text { meningkatkan hubungan sosial saya } \\
\text { dengan orang lain. }\end{array}$ & & & \\
\hline
\end{tabular}


http://journal.univetbantara.ac.id/index.php/jbfe

\section{Loyalitas merek}

\begin{tabular}{|c|l|l|l|l|c|c|}
\hline \multirow{2}{*}{ No } & \multicolumn{1}{|c|}{ Pernyataan } & \multicolumn{4}{|c|}{ Jawaban } \\
\cline { 3 - 6 } & & STS & TS & N & S & SS \\
\hline 1 & $\begin{array}{l}\text { Saya percaya bahwa iPhone merupakan } \\
\text { smartphone terbaik bagi saya. }\end{array}$ & & & & \\
\hline 2 & $\begin{array}{l}\text { Saya mengatakan hal-hal positif tentang } \\
\text { iPhone kepada orang lain }\end{array}$ & & & & \\
\hline 3 & $\begin{array}{l}\text { Saya merekomendasikan iPhone kepada } \\
\text { orang lain yang meminta saran saya. }\end{array}$ & & & & \\
\hline 4 & $\begin{array}{l}\text { Ketika saya perlu melakukan pembelian, } \\
\text { iPhone adalah pilihan pertama saya. }\end{array}$ & & & & \\
\hline
\end{tabular}

